\title{
ДОСВІД ОРГАНІЗАЦІї ВИКЛАДАННЯ ВНУТРІШНЬОЇ МЕДИЦИНИ СТУДЕНТАМ СПЕЦІАЛЬНОСТІ “МЕДИЧНА ПСИХОЛОГІЯ” НА КАФЕДРІ ВНУТРІШНЬОЇ МЕДИЦИНИ, КЛІНІЧНОЇ ФАРМАКОЛОГІЇ ТА ПРОФЕСІЙНИХ ХВОРОБ БУКОВИНСЬКОГО ДЕРЖАВНОГО МЕДИЧНОГО УНІВЕРСИТЕТУ В УМОВАХ КРЕДИТНО-МОДУЛЬНОӦ СИСТЕМИ ОСВІТИ
}

\author{
Г. І. Шумко
}

\section{EXPERIENCE OF ORGANIZATION OF TEACHING ON INTERNAL MEDICINE FOR STUDENTS OF SPECIALTY "MEDICAL PSYCHOLOGY" AT THE DEPARTMENT OF INTERNAL MEDICINE, CLINICAL PHARMACOLOGY AND OCCUPATION DISEASES IN THE CONDITIONS OF CREDIT-MODULAR SYSTEM EDUCATION}

\section{H. I. Shumko}

\author{
Bukovyna State Medical University
}

\begin{abstract}
У роботі представлено досвід організації викладання внутрішньої медицини студентам спеціальності "Медична психологія" на кафедрі внутрішньої медицини, клінічної фармакології та професійних хвороб в умовах кредитно-модульної системи. Наведені основні положення й принципи навчання студентів та форми їх контролю.

Experience of organization of teaching of internal medicine for students of specialty "Medical psychology" at the Department of Internal Medicine, Clinical Pharmacology and Occupation Diseases in conditions of credit-modular system education are described in the article. General positions and principles of this part of the student's teaching, control systems are proposed.
\end{abstract}

Вступ. Сучасні тенденції розвитку України визначаються у загальному контексті Європейської інтеграції з орієнтацією на фундаментальні цінності західної культури, зокрема свободу отримання якісної освіти [1].

Основною метою державної політики в галузі освіти $€$ створення умов для розвитку особистості та самореалізації кожного громадянина України, організації якісної підготовки висококваліфікованих фахівців. Це зумовлює необхідність забезпечення спеціалістів комплексом професійних умінь для реалізації ї виробничої діяльності [2].

Відповідно до європейських стандартів у контексті Болонського процесу має місце уніфікація навчального процесу, використання різноманітних форм навчання, спрямованих на максимальну реалізацію активності, ініціативності та самостійності студентів. Адже підготовка до реальної практичної діяльності - одне з найголовніших завдань вищого медичного навчального закладу [3].

() Г. І. Шумко
Медична діяльність відрізняється тим, що об' єктом дослідження є людина. Найчастіше медицина має справу з хворою людиною, стан якої дуже часто супроводжується особливістю психіки, неврівноваженим емоційним станом, надмірною дратливістю, підвищеною збудливістю, неадекватним сприйняттям свого стану. Тому підготовка майбутніх лікарівпсихологів $є$ досить серйозною та відповідальною справою, яка вимагає особливої роботи з кожним студентом, виховання у нього навичок до такої діяльності [4].

На сьогодні медична система підготовки вчить майбутніх лікарів сучасних технологій та методик лікування, розкриває суть дії численних фармацевтичних препаратів, якими наповнений ринок, аналізує специфіку нових підходів у медицині, широко пропагує доказову медицину. Але одним з основних завдань сучасної медичної освіти є підготовка висококваліфікованих лікарів-психологів, які повинні поєднувати в собі мистецтво комплексної медикопсихологічної допомоги. 
Нині в Україні істотно зростає потреба суспільства в кваліфікованій психологічній допомозі, оскільки перебування в хронічному стресі відчутно дає про себе знати. Допомоги потребують як соматично здорові особистості, так і соматично хворі пацієнти. Ми повинні намагатися наблизити медико-психологічну допомогу паціснтам до сучасних стандартів, здійснюючи підготовку лікарів-психологів, які зможуть надавати необхідну допомогу всім пацієнтам, які цього потребують.

Досить серйозним для викладача завданням, яке вимагає впровадження різноманітних заходів щодо поліпшення підготовки студентів в умовах кредитномодульної системи освіти, є викладання такої клінічної дисципліни, як "Внутрішня медицина" студентам спеціальності “Медична психологія".

Основна частина. Студенти спеціальності “Медична психологія" на практичних заняттях з внутрішньої медицини поряд 3 класичним викладанням матеріалу щодо соматичного хворого вивчають психологічні особливості пацієнтів з різноманітними захворюваннями внутрішніх органів, методи та способи діагностики цих особливостей, диференційну діагностику психологічних особливостей та психопатологічних синдромів. Особлива увага приділяється психології взаємовідношень між пацієнтом та медиком, а також психопрофілактичній та психотерапевтичній допомозі.

Навчання студента деонтологічних принципів спілкування з пацієнтом $€$ важливим аспектом формування майбутнього медичного психолога. Студентам необхідні знання психологічних особливостей хворих для встановлення з ними відповідного контакту. Вони повинні бути делікатними, коректними та проявляти терпіння, особливо працюючи з контингентом старших вікових груп.

Студенти активно працюють біля ліжка хворого, беруть учать в обходах та клінічних розборах важких хворих, застосовуючи набуті знання на практиці. Вони тренують свої вміння та навички щодо опитування хворого, в тому числі збирання психологічного анамнезу з використанням різноманітних психологічних опитувальників. Набувають більшого досвіду при проведенні об'єктивного обстеження хворого. Вони вчаться діагностувати індивідуальні відмінності особистості пацієнта 3 конкретним захворюванням, проводити клініко-психологічне обстеження хворого, застосовувати різні методи психологічного дослідження особистості, а також проводити аналіз та узагальнення результатів обстеження.

Наші студенти вчаться клінічно мислити, визначаючи перелік необхідних додаткових методів до- слідження, в тому числі психологічного статусу пацієнта, проводять диференційну діагностику з синдромоподібними хворими для постановки остаточного правильного діагнозу. Особливе значення надається визначенню характеру медико-психологічної допомоги пацієнту, обгрунтуванню методів лікування з урахуванням індивідуальних особливостей хворого.

Майбутній лікар-психолог повинен тісно співпрацювати з лікуючим лікарем, оскільки психологічний стан хворих має великий вплив на ефективність запропонованої терапії та успішність соціальної реабілітації, особливо в пацієнтів 3 не зовсім неадекватним ставленням до захворювання та лікування. Досить важливим $€$ залучення студентів до проведення з хворими психопрофілактичних бесід.

Закріплення теоретичних знань та їх інтеграція в практичні навички досягається в систематичному безпосередньому спілкуванні з хворими. Свій результат щодо роботи з хворими під час вивчення внутрішньої медицини студент повинен продемонструвати також у вигляді написання навчальної історії хвороби після здійснення курації вибраного викладачем відповідного хворого. Згідно з тематичним планом практичних занять для проведення курації хворих виділяється окреме заняття, яке оцінюється викладачем.

При підборі хворих для курації викладач намагається охопити якомога більшу кількість різноманітної соматичної патології для того, щоб кожен студент працював індивідуально зі своїм пацієнтом, розвиваючи своє особисте клінічне мислення.

Увага студентів акцентується на правильне відображення найбільш важливих для подальшої практичної діяльності моментів. Звертається увага на скарги хворого на день курації студентом з урахуванням як основного захворювання, так і його ускладнень та супутньої патології. Висвітлюються основні моменти щодо анамнезу хвороби та життя. Лаконічно оцінюється об'єктивне дослідження хворого, ретельно описуються клінічно значущі відхилення від норми. Описується провідна симптоматика, що дає можливість запідозрити у хворого відповідну патологію. Студент повинен провести обгрунтування кожного пункту попереднього діагнозу окремо на основі виявлених у пацієнта змін.

Особливо ретельно студент повинен викласти дані додаткових методів дослідження, які необхідно провести саме в даного конкретного хворого для встановлення діагнозу з обгрунтуванням доцільності методу обстеження. Також студент повинен провести диференційний діагноз з двома найбільш подібними за клінічними проявами та топічною локалізацією 
захворюваннями на свій вибір, що демонструє уміння логічно мислити. Велике значення має чітке формулювання клінічного діагнозу з обов'язковим розподілом на основне захворювання, ускладнення та супутні захворювання.

Лікування слід призначати кожному конкретному хворому з урахуванням ускладнень та супутньої патології із заповненням листка лікарських призначень. Обов'язковим є обгрунтування кожного призначення та написання рецептури медикаментозних засобів, що використовуються у даного пацієнта. Також слід написати план щодо реабілітації хворого, в тому числі психологічної.

Кафедра внутрішньої медицини, клінічної фармакології та професійних хвороб розробила методичний посібник для студентів, де представлена схема написання навчальної історії хвороби.

Після написання навчальної історії хвороби пацієнта студентами та її перевірки викладачем проводиться практичне заняття щодо захисту навчальної історії хвороби, за яке теж передбачена окрема оцінка. На даному занятті студент має можливість виправити та обгрунтувати всі допущені при написанні навчальної історії хвороби помилки.

\section{Література}

1. Пидаев А. В. Болонский процесс в Европе / А. В. Пидаев, В. Г. Передерий. - Одесса : Одес. гос. ун-т, 2004. - 192 с.

2. Думанський Ю. В. Освоєння студентами практичних навичок при кредитно-модульній організації навчального процесу: проблеми та пошук їх вирішення / Ю. В. Думанський, О. М. Талалаєнко, М. Б. Первак // Медична освіта. 2011. -№3. - С. 79-81.
Такий підхід дозволяє сформувати основні практичні навички та вміння, необхідні лікарю-психологу при наданні медичної допомоги хворому та дозволяє оптимізувати робочий час викладача.

Забезпечення вивчення внутрішньої медицини студентами базується на широкому використанні не тільки новітніх технологій, але й щоденній праці над собою та освоєнням практичних навичок біля ліжка хворого. Наша мета як педагогів і наставників - не лише допомогти в опануванні студентом практичних навичок і вмінь обстеження та лікування хворого, але й навчити його спілкування з хворою людиною, намагатись виховати в ньому милосердя та співчуття.

Висновки. Організація викладання внутрішньої медицини студентам спеціальності “Медична психологія" на кафедрі внутрішньої медицини, клінічної фармакології та професійних хвороб намагається сприяти підвищенню якості підготовки майбутніх лікарів-психологів, які відповідатимуть сучасним стандартам шляхом активного залучення студентів до клінічної практики біля ліжка хворого, участі їх в обходах та клінічних розборах важких хворих, формування у них клінічного мислення з наступним написанням навчальної історії хвороби.

3. Волосовець О. П. Питання якості освіти у контексті впровадження засад Болонської декларації у вищій медичній школі / О. П. Волосовець // Медична освіта. - 2005. -№2. - С. $12-16$.

4. Алексеєнко Р. В. Формування професійних умінь у майбутніх лікарів як педагогічна проблема / Р. В. Алексеєнко // Медична освіта. - 2012. - № 3 (додаток). - С. 14-16.

Отримано 13.05.14 